\title{
THE LEAD MAN CONCEPT: A COMPREHENSIVE PROGRAM FOR EFFECTIVE EMPLOYEE SOCIALIZATION
}

Fabius P. O'Brien and Donald A. Drost

A great deal of research attention has been focused on organizational socialization - the transformation of "new recruits from total outsiders to participating and effective members of work organizations (Feldman, 1981, p. 309). This body of research has been devoted almost exclusively to the socialization of managers (Berlew and Hall, 1966; Buchanan, 1974; Porter, Lawler and Hackman, 1975; and Feldman, 1976) and to career development (Van Maanen, 1976 and Schein, 1978). The majority of organizational participants, those occupying jobs in the lower strata of the organization, have been largely ignored, perhaps because persons occupying blue-collar and service jobs have not been viewed as "career" employees. Yet these jobs are eritical to organizational functioning as they directly involve the manufacture of a product or delivery of a valued service. This paper points out some of the problems with the primitive socialization of new recruits in the nonmanagerial ranks and recommends a program which has led to productive and committed nonmanagerial employees in a number of work organizations.

\section{THE EMPLOYEE SOCIALIZATION PROCESS}

Employees socialization is a continuous process in which new recruits are introduced to the "norms" of the organization. Formal socialization programs such as those employed by some firms for managers, can be effective in helping new employees learn what the company expects of them. Since employers know from experience that adjustment to a new environment requires time, the acquisition of new skills, development of new work role relationships, etc., formal programs may be employed to help new recruits adjust. This may involve the development of a mentorship in which the new employee is nurtured to become a "team player." The idea is to effect a match between new recruits and the employer that will endure, and which will result in committed and productive employees.

Socialization continues throughout an individual's tenure in a particular work organization and is viewed as a maturation process of mutual accommodation by the individual and his/her employer. Nonmanagerial employees are rarely the subjects of such formal efforts. Their "socialization" is informal, uneven, at best, and often counterproductive.

For many nonmanagerial employees, this informal socialization process begins even before job recruitment. Unless a company is in a new locale, prospective job applicants already have an image of the company and perhaps the jobs and work groups there. The sharing of information among workers in a community who do similar work leads to certain expectations about the company. These expectations may be good or bad, correct or incorrect. The first opportunity which employers normally have to "set the record straight" about the company comes during the recruitment process. 
The Recruitment of New Employees

Recruitment involves the establishment of a pool of qualified applicants for various positions of one or more jobs. It generally means the use of advertising through printed media (newspapers, trade journals, magazines, etc.) or through broadcast media (radio and television). Persons available as job applicants may also be secured through current or former employees, past applications and "walk ins." Recruitment may involve either telephone or face-to-face interviewing as initial screening devices in the match between the individual and the prospective employer. Often, initial interviews are conducted for employers by state employment representatives, as well. Unlike the situations for managers, however, recruiting interviews are not generally used to entice new recruits as the relatively low skill required for jobs at this level results in more applicants than available positions. The demand for jobs at this level is so great relative to their supply, that employers rarely attempt to "woo" new recruits.

Whereas managerial job applicants often are encouraged to ask questions about their work, salary, and the product or service with which they will be involved, a "take it or leave it" posture for nonmanagerial applicants inhibits a realistic preview of the job. Setting the record straight is simply not of interest to the employer.

The Selection Process

Since applicants generally exceed the number of available positions, selection of the best qualified candidates from the applicant pool is necessary. This procedure is relatively uncomplicated when compared with the selection of managerial or professional employees. Applicants qualify based upon their performance on ability tests, their job experience and a number of other potential predictors of successful job performance.

If a number of positions within the same job category are vacant within a company, new recruits may be hired without them first meeting their prospective supervisors or actually visiting their work area. Even when new recruits are hired for a specific position by the supervisor, the transition from "outsider" to "insider" is generally rather abrupt. This is regrettable because this period represents a critical one if socialization is to be effective. Beyond this point, the new recruit may be influenced by other employees or groups who may not have the best interests of the organization at heart. Supervisors tend to rely upon employee orientation programs to provide the "social amenities" for new recruits.

\section{Employee Orientation}

Most organizations have a day-long or part-day orientation to the formal organization. This often includes an explanation of general topics of interest, such as fringe benefits, pay days, company parking, probation status, and many other personnel policies. In the more enlightened firms employee handbooks 
are distributed to each employee and discussed in some detail. Orientation may result in a "quiz" to determine whether and to what extent information has been absorbed.

In unionized firms, orientation may be an opportunity for new hires to first meet union officials. It may also be an introduction to the labormanagement agreement which will govern aspects of work dealing with wages, hours and other terms and conditions of employment. New employee rights and responsibilities under the contract are often explained. Invariably, employees are made aware of whether they will have to join the local union and how this will take place. In unionized firms, orientation may thus create images of divided loyalty which tend to undermine clear lines of authority.

Employee orientation may work well as part of a manager's socialization program; however, this does not necessarily hold true for nonmanagerial employees. Managers are trained to view the organization as a "whole" and topics of general scope may be effective in helping clarify the "big picture." Nonmanagerial employees may view orientation as somewhat more overwhelming since they tend to view their world of work as restricted to their job or their work group. Alienation created by crude attempts or by no attempts by the employer to formally socialize the new recruit forces closer relations between the new recruit and his/her work group. The manager thereby loses control over the employee's socialization process.

\section{Informal Groups at Work}

No matter what relationship has developed between individual employees and supervisors during the first several days following selection, the new employee will meet and must work with others in his/her work area. The degree of reliance which the new employee feels for the informal group depends upon the relationship which he/she has established with the supervisor thus far. If it has been cold and/or abrupt, feelings of alienation have already begun. Since new employees are generally on probation for at least thirty days, interest in survival is intensified. If the employee feels alienated from his/her supervisor, he/she will turn to other work group members for help to learn the appropriate work role behavior.

Work groups are collections of employees who are assigned to work together to manufacture a product or deliver a service. The combined effort of their work results in measurable performance. If the new employee survives with the help of peers, the work group will be the organizational entity with which the employee most closely identifies. The new employee's informal socialization is a naturally occuring process brought about by the mutual rights and obligations of informal group membership.

Work groups satisfy distinctive needs for the new employee. Group members are generally willing to provide informal training and advice for new employees - show them the ropes. Whereas the formal work organization details procedures for work, informal groups operate to circumvent them, to establish 
short cut procedures to get work done more quickly. Short cuts and work savings procedures are rarely shared with the supervisor for fear that such an action will result in a higher production standard.

Incumbent employees who are work group members may have experienced much the same interaction with the supervisor. Such behavior acts to reinforce group norms for survival. Regrettably, these group norms may act against the best interests of the company. They serve to maintain the informal group and only coincidentally, the company. Thus, the informal group has done for the new employee what the company was unable or unwilling to do. It has provided training and a set of informal rules which govern work behavior. In exchange, the group demands conformity by the employee to group norms.

This group indoctrination or socialization process acts to reinforce the differences between supervisors and subordinates instead of bringing them closer together. When these differences are threatening to employees, they sometimes seek union representation when none exists.

Formal Groups at Work - The Labor Union

When informal work groups band together to organize a labor union, their interests are protected by a formal group of employees, the local union. New recruits may benefit from union membership to the extent that union officials and members may help socialize new employees. Union officials and members provide a formal network of experienced employees to show new employees "the ropes." This is particularly the case in large organizations with routine technologies in which spans of management are generally quite large. This prevents supervisors from spending enough time with new employees to insure that they become effective performers. While it is clear that labor unions do not intend to topple the company with. which they co-exist, they demand loyalty from new recruits and conformity to a set of rules, both formal (by-laws) and informal (work restriction norms), which do not ordinarily result in the most effective job performance.

Work group involvement in the socialization process, whether a formal or an informal group, serves to demonstrate that management has abdicated its power to other organizational entities which do not necessarily have the best interests of the work organization at heart. The principles underlying formalized employee socialization programs are clearly in the best interests of organizational effectiveness and should be considered for nonmanagerial employees, as well. Following is a comprehensive program for nonmanagerial employees which combines the best features of human resource management programs designed to make the transition from "outsider" to "insider" a smooth and productive endeavor.

\section{THE INFORMAL GROUP LEADER: A POTENTIAL "SILENT PARTNER"}

One feature of informal groups of primary importance in the socialization of new employees is the informal group leader (IGL). The IGL may be an 
"opinion leader" to the extent that he/she speaks for the group on issues of common interest. He/she may also be a "social facilitator," an individual who organizes activities for the group, resolves disputes, and generally effectuates the smooth operation of informal group activity. Often the "opinion leader" and the "social facilitator" are one in the same.

We tend to think of leaders in the "formal sense." This is, a leader of a formal organization, i.e., political party, baseball team, or a corporation. Leaders share a similar motivation structure in that they are "driven" to persuade and influence the activity of others. IGL's are no different. They typically have a strong need to achieve. Moreover, their power base is effective because it extends beyond simple charisma. IGL's are respected for their technical ability or "expert power." They often use these skills to aid fellow work group members. It is not uncommon for supervisors to seek their advice regarding technical matters and new ideas. In short, IGL's can be creative, highly motivated "silent partners" of the employer.

\section{FROM INFORMAL GROUP LEAD TO "LEAD MAN"}

One concept which allows the employer to take full advantage of the IGL's leadership ability and technical expertise is that of "lead man." A lead man (LM) is not a supervisor, per se, but assumes some of the supervisor's responsibilities. For example, the major function of the LM is the training of new recruits. Their training can be particularly effective since new recruits recognize the LM as a member of a valuable support group. A major barrier of formality is broken down and learning is enhanced. The LM works beside trainees, serving as a productive role model. In a sense, this is the "mentorship" arrangement many management recruits experience throughout their career development.

A second function is that of "trouble shooter." Everyone in the work group benefits from the LM's skill and his/her new role provides stimulation, recognition, and the opportunity for advancement. Not all IGL's want to become managers, however. Most have strong needs for affiliation - loyalty to the group. IGL's often fear the loss of friendship should they accept promotion, and the power relationship they enjoyed without using coercion.

The role of trouble shooter, however, may provide a vehicle to gradually move the best IGL's into supervisory positions. It provides a method whereby fellow workers get to "try on" the idea of having a close friend in a formal leadership role. Moreover, LM's are paid greater wages than those that they oversee. Fellow employees recongize that the LM's responsibilities are different than theirs and worthy of differential rewards. The transition is less abrupt and constitutes an ideal method of socializing new supervisors, as we11. In essence, their tenure as lead men is a realistic preview of what they might expect in the role of manager. 


\section{PUTTING THE PIECES TOGETHER}

While the IGL serving as a LM is the key ingredient to effective nonmanagerial employee socialization, a formal program is required to enjoy the full benefits suggested earlier. First, it is important to recognize the value of treating nonmanagerial employees well from the outset. Even when jobs are relatively monotonous in nature, a "realistic preview" of the job can go a long way toward helping new recruits manage their expectations for the job and/or employer. The LM can be particularly helpful at this juncture. $\mathrm{He} / \mathrm{she}$ can provide recruiters with insights about the job itself, the technological process, the working conditions, etc. The LM may be present in subsequent interviews to answer questions and offer information about the job, work group, or their own view of the company. The supervisor may also seek the LM's advice about job applicants before making selection decisions.

Initial orientation may feature a tour of the work site, break facilities and an introduction to fellow work group members, an ideal task for the LM. The LM's sponsorship increases the likelihood that the new employee will be accepted by fellow workers. Moreover, close personal supervision during training enhances the likelihood that the new recruit will become an effective performer. The new employee can also see that promotion within the company is possible through the LM's example. Such images create value in the job. This may be viewed as an initial, but important step to greater reward. A positive beginning of this nature will do much to develop loyalty to the employer are to demonstrate that the employer is not simply trying to exploit a new source of labor.

It is also important to recognize that the socialization process is continuous. Learning about personnel policies, the rigors of the job and the work group are but one stage of socialization. An effective socialization effort should focus on the long run and instill the worker with a sense that he/she plays a vital role within the organization. Here to, the LM can be an impressionable force. The LM can inculcate values of commitment toward higher productivity, pride in craftsmanship and creativity - values which often distinguish the "excellent" organization from the "ordinary" organization. The LM approach of continuous socialization will yield far better longterm results than the "lip service" often provided through an inspirational speech at the time of initial:employment.

\section{CURRENT APPLICATIONS}

Formal nonmanagerial employee socialization programs which employ informal group leaders as lead men are applicable to a wide range of organizations and occupations. They have been used effectively in production operations for many years. Even seasoned machine operators who are newcomers need to learn how to do it "our way."

Lead man socialization programs have also been used effectively in typing pools to help new typists learn company policies, rules, forms and filing systems. Retail sales chains sometimes use lead men, too, in shoe, clothing, sporting goods and household goods departments, for example. These 
programs help acclimate new sales persons to price and discount policies, styles and sales and refund policies. Even when fellow employees compete for commissions in retail sales, they quickly learn that well trained peers help create demand for products and services that would be lost otherwise.

\section{CONCLUSIONS}

Clearly, the new employee and the employer benefit from formal socialization programs. In this case, employers have the opportunity to harness one of their key resources, the informal group leader. By embracing the concept of the lead man as a mentor to new employees, the benefits to the organization are numerous. First, the employee enjoys a smooth transition into the work place. A smooth transition in place of the usual alienation associated with job entry should reduce turnover among the newly hired (the group which traditionally has the highest turnover rate). Secondly, the employee will more readily be able to adapt to the demands of the job. This should result in higher productivity and quality and fewer costly errors. Finally, the new entrants will be instilled with the behaviors and values that successful organizations require. That is the hallmark of formal employee socialization programs.

\section{REFERENCES}

Berlew, D.E., and Hall, D.T. (1966). The Socialization of Managers: Effects of Expectations on Performance. Administrative Science Quarterly, 11, 207-223.

Buchanan, B. (1974). Building Organizational Commitment: The Socialization of Managers in Work Organizations. Administrative Science Quarter1y, 19, 533-546.

Feldman, D.C. (1976). A Contingency Theory of Socialization. Administrative Science Quarter1y, 21, 433-452.

Feldman, D.C. (1981). The Multiple Socialization of Organizational Members. Academy of Management Journal, 6, 309-318.

Porter, L.W.; Lawler, E.E.; and Hackman, J.R. (1975). Behavior in Organizations. New York: McGraw-Hill.

Schein, E.H. (1978). Career Dynamics: Matching Individual and Organization Needs. Reading, MA: Addison-Wesley.

Van Maanen, J. (1978). People Processing: Strategies of Organizational Socialization. Organizational Dynamics, 7, 18-36. 